ORL 1992;54:I-IV

\title{
Contents, Vol. 54, 1992
}

\section{No. 1}

No. 2

Window to the East

\section{Editorial Note 1}

Use of the Medicinal Leech in the Treatment of Ear Diseases 1

Seleznev, K.G.; Shchetinina, E.A.; Trophimenko, N.P.; Nikonov, G.I.; Baskova, I.P.

Original Paper

Ciprofloxacin and the Inner Ear - A Morphological and Round 5 Window Membrane

Permeability Study Bagger-Sjöbäck, D.; Lundman, L.; Nilsson-Ehle, I.

Study of the Effect of $350-\mathrm{Hz}$ Tone Exposure on Electrophysio- 10 logical Function of the Inner Ear of Guinea Pigs

Yamamura, K.; Sugisawa, T.; Inada, N.; Matsui, T.; Ishida, A.

Pathogenesis of Widened AP-SP Complex in Cases of Cerebel- 15 lopontine Angle Tumors Takeda, T.; Kitahara, M.; Sawada, I.

A Modified Method of Electronystagmography for Recording 21 Eye Movement during the Galvanic Vestibular Test Straub, R.H.; Thoden, U.

In vivo Attachment of Streptococcus pneumoniae and Haemo- 25 philus influenzae to

Nasopharyngeal Epithelium in Children Stenfors, L.-E.; Räisänen, S.

Evidence of Platelet-Activating Factor in Nasal Polyps

Furukawa, M.; Yamashita, T.; Kumazawa, T.; Satouchi, K.; Saito, K.

Studies on the Regranulation of Salivary Gland Serous Cells. 33 An Electron Microscopical Study in the Rat Gemryd, P.; Norberg, L.E.; Lundquist, P.-G.

Regeneration of Free Grafted Respiratory Epithelium on 38

Severely Altered Lamina propria Bootz, F.;Kempf, H.G.

Supraglottic versus Glottic Laryngeal Cancer: Epidemiological 43

and Pathological Aspects

Silvestri, F.; Bussani, R.; Stanta, G.; Cosatti, C; Ferlito, A.

Effects of Topical Laryngeal Lidocaine on Sympathetic 49

Response to Rigid Panendoscopy under General Anesthesia Gaumann, D.M.; Tassonyi, E.;

Fathi, F.; Griessen, M.

Case Reports

Heterotopic Brain Tissue of the Soft Palate 54

Fuse, T.; Aoyagi, M; Ota, N.; Koike, Y.; Yuda, F.

Tuberculous Otomastoiditis 57

Mjøen, S.; Grøntved, A.; Holth, V.; Mair, I.W.S.

Book Reviews 60

Original Paper

Sensorineural Hearing Loss Associated with Otitis media with 61 Effusion

Harada, T.; Yamasoba, T.; Yagi, M. 
Idiopathic Sudden Hearing Loss and Disturbance of Iron 66

Metabolism. A Clinical Survey of 426 Cases Sun, A.-H.; Wang, Z.-M.; Xiao, S.-Z.; Li, Z.-J.;

Ding, J.-C; Li, J.-Y.; Kong, L.-S.

Electronystagmographic Features in Some Peripheral and 71

Central Vestibular Disorders: Application of Multiple Discriminant Analysis of

Electronystagmographic Parameters Wei, G.; Yu. L.S.; Liu, C; Li, G.Q.; Zhang, R.; Chen, S.H.

Functional Study of the Eustachian Tube with Sequential 76

Scintigraphy

Paludetti, G; Di Nardo, W.; Galli, J.; De Rossi, G.; Almadori, G.

Culture and Cryopreservation of Chondrocytes from 80

Human Cartilage: Relevance for Cartilage Allografting in

Otolaryngology

Bujía, J.; Pitzke, P.; Wilmes, E.; Hammer, C.

Immunohistochemical Study of the Fourth Cell Type in the 85

Olfactory Epithelium in Guinea Pigs and in a Patient Yamagishi, M.; Nakamura, H.; Nakano, Y.;

Kuwano, R.

Empty Sella Syndrome, Diagnosed as Allergic Rhinitis 91

Gonianakis, M.; Segas, J.; Kontou-Fili, K; Bizakis, J.; Christodoulou, P.; Velegrakis, G.;

Helidonis, E.

Phlegmonous and Abscess-Forming ENT Infections: Compara- 95 tive Efficacy of Ceftriaxone

versus Amoxicillin-Clavulanic Acid Panosetti, E.

Personal Experience of Horizontal Glottectomy. Critical 100

Evaluation of Long-Term Results Calearo, C; Merlo, R.

Elective Radiotherapy of the Neck in Patients with Squamous 103

Cell Carcinoma of the Head and Neck

Boysen, M.; Lövdal, O.; Söberg, R.; Jacobsen, A.-B.; Tausjö, J.;

Evensen, J.F.

Case Reports

Keloids of the External Ear 108

Buchwald, C; Nielsen, L.H.; Rosborg, J.

Vestibular Disturbance after Myelography. Contrast Media in 113 the Internal Auditory Canal

Mizuno, M.; Yamasoba, L.; Nomura, Y.

Book Review 116

Announcements $\quad 90,99$

II

No. 3

Original Paper

Calmodulin Binding Sites in the Endolymphatic Sac and Stria 117 vascularis of the Human Fetus and the Guinea Pig Yamashita, H.; Bagger-Sjöbäck, D.

The Length of Isolated Outer Hair Cells Is Temperature

Dependent

Gitter, A.H.

Histochemical Localization of Glycoconjugates in the

Developing Endolymphatic Sac and Vestibular End Organs of the Mouse Yamashita, H.;

Bagger-Sjöbäck, D.; Sekitani, T.

Effect of Ambroxol on Rabbit Eustachian Tube Surfactant 130 
Mira, E.; Benazzo, M; Manzoni, M.; Lligona, L.; Salmona, M.; Tacconi, M.T.

Evaluation of the Galvanic Vestibulo-Ocular Response 133

Recorded with a Modified Electronystagmographic Technique Straub, R.H.; Thoden, U.

Diagnosis of Cerebellopontine Angle Tumors 139

Guyot, J.-P.; Häusler, R.; Reverdin, A.; Berney, J.; Montandon, P.B.

Middle Ear Inflation with a Gas Mixture 144

Shinkawa, H.; Hozawa, J.; Takasaka, T.

Cochlear Function after Stapedectomy $\quad 148$

Ghonim, M.R.

Effect of $3 / 4$-Blockers, Cimetidine and Famotidine, on $\quad 152$

Histamine Nasal Provocative Test

Ogino, S.; Irifune, M.; Harada, T.; Matsunaga, T.

Direct Observation of Living Laryngeal Carcinoma Cells 155

during Invasion of Healthy Cell Formation Bootz, F.; Zenner, H.P.

Case Reports

Ventricular Fibrillation following Local Application of $\quad 160$

Cocaine and Epinephrine for Nasal Surgery Lormans, P.; Gauman $\pi$, D.; Schwieger, I.; Tassonyi, E.

Laryngeal Paraganglioma and Pregnancy 163

Werner, J.A.; Hansmann, M.-L.; Lippert, B.M.; Rudert, H.

Book Review 168

Announcements $\quad 159,167$

No. 4

Functional Morphology of the Human Endolymphatic Sac. 173

A Review

Altermatt, H.J.; Gebbers, J.-O.; Müller, C; Arnold, W.; Laissue, J.

Cytodifferentiation within the Developing Human Endo- 179

lymphatic Sac Bagger-Sjöbäck, D.

Origin of Sympathetic and Sensory Innervation of the Endo- 188 lymphatic Sac. A Retrograde

Axonal Tracing Study in the Guinea Pig Birgersson, L.; Friberg, U.; Rask-Andersen, H.; Erwall, C; Widenfalk, B.

Osmotically Induced Macrophage Activity in the Endolym-191

phatic Sac. On the Possible Interaction between Periaqueductal Bone Marrow Cells and the

Endolymphatic Sac Jansson, B.; Rask-Andersen, H.

Acidity in the Endolymphatic Sac Fluid of Guinea Pigs 198

Tsujikawa, S.; Yamashita, T.; Amano, H.; Kumazawa, T.; Vosteen, K.-H.

Effects of Glycerol on the Endolymphatic Sac. A Time 201

Sequence Study

Jansson, B.; Friberg, U.; Rask-Andersen, H.

Microorganism Transport in the Human Endolymphatic Duct 211 Danckwardt-Lillieström, N.;

Friberg, U.; Rask-Andersen, $\mathrm{H}$.

A Technique to Obtain and Process Surgical Specimens of the 215 Human Vestibular Aqueduct

for Histopathological Studies of the Endolymphatic Duct and Sac

Danckwardt-Lillieström, N.; Rask-Andersen, H.; Linthicum, F.H.; House, W.F.

Cochlear Structure and Function in a Recessive Type of 220

Genetically Induced Inner Ear Degeneration Sjöström, B.; Anniko, M. 
No. 5

Window to the East

Evoked Otoacoustic Emission: Behaviour under the Forward 229

Masking Paradigm

Kevanishvili, Z.; Gobsch, H.; Gvelesiani, T.; Gamgebeli, Z.

Original Paper

Development of the Endolymphatic Sac in Chick Embryos, 235

with Reference to the Degradation of Otoconia

Yoshihara, T.; Kaname, H.; Narita, N.; Ishii, T.; Igarashi, M,; Fermin, CD.

Cell Membrane Polarity of the Epithelial Cells in the Endo- 241

lymphatic Sac of the Guinea Pig

van Benthem, P.P.G.; Albers, F.W.J.; de Groot, J.C.M.J.; Veldman, J.E.; Huizing, E.H.

Sudden Sensorineural Hearing Loss Induced by Experimental 246

Iron Deficiency in Rats

Sun, A.-H.; Wang, Z.-M.; Xiao, S.-Z.; Li, Z.-J.; Zheng, Z.; Li, H.-Y.

Diagnosis of the Ossicular Chain in the Middle Ear by

251

High-Resolution CT

Fuse, T.; Aoyagi, M.; Koike, Y.; Sugai, Y.

Stapedial Reflex in Parkinson's Disease 255

Murofushi, T.; Yamane, M.; Osanai, R.

Infrared Laser Tissue Ablation: Holmium:YAG Laser Surgery 259 Experience with the Cochlear Miniature Speech Processor in 308

Kautzky, M.; Susani, M.; Schenk, P. Adults and Children Together with a Comparison of

Unipolar

and Bipolar Modes

Quantitative DNA Measurements in Malignant and Benign 264 Lehnhar 328 E. Gnadeberg, D,

Battmer, R.D, von Wallenberg. E.

Lesions of the Upper Aerodigestive Tract

Welkoborsky, H.-J.; Mann, W.; Gluckman, J.; Freije, J. Geneva Experience with the Ineraid

Multichannel Cochlear 314

Implant

Effect of Oxymetazohne Nose Drops on Vascular Permeability 270Montandon p . pdizzone M,

Kasper A, Rohr A

of the Nasal Mucosa in the Rabbit after Provocation with

Leukotriene B4 Psychological Adaptations and Emotional Observations of 317

Bende, M; Hansell, P.; Intaglietta, M.; Arfors, K.-E. Eight Multichannel Cochlear Implant

Patients

Degive, C; Archinard, M.

Indispensability of Mediastinoscopy in Intrathoracic275

Tuberculosis Case Report: Top Hearing Performances of a Postlingually 320

Salomaa, E.-R.; Liippo, K.; Puhakka, H.J.; Tala, E. Deaf Cochlear Implant User

Case Reports

Bucher. P.O.; Mathis, A.; De Min, N.; Arnold, W.

Original Paper

Labyrinthine Anomalies with Normal Cochlear Function 278

Mizuno, M.; Harada, T. Autograft Ossiculoplasty in Cholesteatoma 324 
El Seifi, A.; Fouad, B.

Penetrating Wounds of the Ear with Oval Window Fistulas: 282

Reports of 2 Cases $\quad$ Ear Polyps in Posterior Superior Retraction Pockets, Herodion. 328

Guyot, J.-P. Histopathological and Pathogenetic Aspects

Larsen, P.L.; Tos, M.

Announcements 263

Case Report

An Unusual Case of Castleman's Disease Restricted to the 331

Neck

Sanz, C; Sierra, J.; Cobarro, J.; Avellaneda, R.; Montserrat, E.;

Rozman, C.

Original Paper/Cochlear Implants

Electrically Evoked Auditory Brainstem Responses in 28

Cochlear Implant Patients Candida and Stapedial Otosclerosis: Histopathological

Kasper, A.; Pelizzone, M.; Montandon, P. Findings

Exploratory Cochleotomy. Assessment of Auditory Nerve $295 \quad$ 1/8 ${ }^{\wedge}$ if. $1 / 8 .{ }^{\wedge 1} / 8 h^{1} / 8^{\mathrm{TM}} \wedge^{\prime}$

Excitability and Anatomical Conditions in Cochlear Implant Window to the East

Candidates

Montandon, P.; Kasper, A.; Pelizzone, M. Abstracts 337

Digital Speech Processing for Cochlear Implants 299 Author Index 341

Dillier, N.;Bögn, H.;Spillmann, T. Subject Index 343

S. Karger

Medical and Scientific Publishers Basel · Freiburg · Paris · London New York · New Delhi ·

Bangkok Singapore $\cdot$ Tokyo $\cdot$ Sydney

Drug Dosage

The authors and the publisher have exerted every effort to ensure that drug selection and dosage set forth in this text are in accord with current recommendations and practice at the time of publication. However, in view of ongoing research, changes in government regulations, and the constant now of information relating to drug therapy and drug reactions, the reader is urged to check the package insert for each drug for any change in indications and dosage and for added warnings and precautions. This is particularly important when the recommended agent is a new and/or infrequently employed drug.

All rights reserved.

No part of this publication may be translated into other languages, reproduced or utilized in any form or by any means, electronic or mechanical, including photocopying, recording, microcopying, or by any information storage and retrieval system, without permission in writing from the publisher or, in the ease of photocopying, direct payment of a specified fee to the Copyright Clearance Center (see 'Information for Readers and Subscribers').

(C) Copyright 1992 by S. Karger AG, P.O. Box, CH-4009 Basel (Switzerland) Printed in Switzerland on acid-free paper by Thür AG Offsetdruck. Pratteln

IV 